Cahiers $d u$ MONDE RUSSE

\section{Cahiers du monde russe}

Russie - Empire russe - Union soviétique et États indépendants

55/3-4 | 2014

Varia

\title{
Ivan IV as Autocrat (Samoderzhets)
}

\section{Charles J. Halperin}

\section{OpenEdition \\ Journals}

\section{Electronic version}

URL: http://journals.openedition.org/monderusse/8000

DOI: 10.4000/monderusse. 8000

ISSN: $1777-5388$

\section{Publisher}

Éditions de l'EHESS

\section{Printed version}

Date of publication: 1 July 2014

Number of pages: $197-213$

ISBN: 978-2-7132-2441-6

ISSN: $1252-6576$

\section{Electronic reference}

Charles J. Halperin, «Ivan IV as Autocrat (Samoderzhets) », Cahiers du monde russe [Online] 55/3-4 | 2014, Online since 01 July 2018, Connection on 01 May 2019. URL : http:// journals.openedition.org/monderusse/8000 ; DOI : 10.4000/monderusse.8000

This text was automatically generated on 1 May 2019.

(c) École des hautes études en sciences sociales 


\title{
Ivan IV as Autocrat (Samoderzhets)
}

\author{
Charles J. Halperin
}

1 However much specialists on the reign of Ivan IV, Ivan Groznyi (the Terrible) (1533-1584) disagree, almost all scholars agree that Ivan was an "autocrat" (samoderzhets) and that his regime was an "autocracy" (samoderzhavstvo). Discussions of the Muscovite political system during Ivan's reign analyze the theory and practice of "autocracy" and Ivan is habitually described as an "autocrat." Such an approach to Ivan originated in Imperial Russian historiography and has continued unabated ever since in Soviet and post-Soviet Russian and Western historiography. Vasilii Kliuchevskii discussed Ivan's theory of "autocracy" (samoderzhavie). ${ }^{2}$ Mikhail D'iakonov opined that in Ivan's opinion only a hereditary unlimited ruler was an "autocrat." ${ }^{3}$ Ruslan Skrynnikov frequently called Ivan "an autocrat." Titles of books about Ivan in Russian, German and English invoked the concept of autocracy. ${ }^{5}$

The only dispute in contemporary scholarship is over whether the autocracy was real or a facade. ${ }^{6}$ It is therefore appropriate to examine not only whether Ivan described himself officially or unofficially as an "autocrat" and whether government or church writers during his reign described him as an "autocrat" but also what meaning the terms "autocrat" and "autocracy" carried in those sources. This essay will show that "autocrat" was employed, albeit inconsistently and rarely, in official state and even church titulature but occurred far more often in Muscovite discourse than in any official documents. ${ }^{7}$ Like most Muscovite political concepts, the term was multivalent. How many meanings were attached to it remains an open question, but this article will discuss three : independent ruler, pious ruler, and unlimited ruler. ${ }^{8}$ In some cases the meaning attached to the term remains unclear and definitions can only be inferred from context. Muscovy was not a constitutional regime so the term never possessed a fixed juridical meaning. The meanings discussed here overlapped and in a single occurrence might have had multiple meanings ; however, each of these three meanings manifested a distinctive emphasis. We will examine in turn the sources which illustrate each meaning, including those written after Ivan's death, noting provenance (state, church, or both), official or unofficial status, genre and function. Given how much documentation from the reign of Ivan IV has not survived, such as the archive of the oprichnina, and how much surviving documentation 
remains unpublished and therefore, unfortunately, inaccessible to me, my analysis must be considered no more than suggestive. Nevertheless tentative conclusions can be drawn from this Begriffsgeschichte. Although historians who describe Muscovy as an "autocracy" almost always mean a state whose ruler possessed unlimited authority, in Ivan's time the most widespread use of "autocrat" was a pious ruler.

\section{"Autocrat" as "Independent Ruler"}

3 "Autocrat" was not a regular part of Ivan's official titulature because Ivan's coronation in 1547 did not accord him that title. ${ }^{9}$ The coronation ordo survives in two major redactions which differ especially in their description of the rite of anointing; neither may be a literal account of the actual coronation. However no version of the ordo ascribed the title "autocrat" to Ivan. Ivan IV's son Tsar Fedor Ivanovich was the first Tsar of Moscow crowned "autocrat" in $1584 .^{10}$ Nevertheless Ivan did use the word for himself and his son and then designated heir Tsarevich Ivan in official diplomatic correspondence. ${ }^{11}$ Aleksandr Filiushkin brought these unpublished texts to the attention of scholars. ${ }^{12}$ In October 1564 and March 1566 Tsarevich Ivan wrote the Crimea to complain of Crimean raids on Riazan'. ${ }^{13}$ According to Filiushkin, given the circumstances the Royal Council (Duma) decided that it was inappropriate for Ivan himself to write Devlet Girei, so instead an epistle to the Crimean kalga, the heir-apparent Tsarevich Mukhammed Girei, was attributed to Tsarevich Ivan. ${ }^{14}$ To raise Tsarevich Ivan's status his title included the word "autocrat." According to Filiushkin originally in Russia, unlike in Byzantium, the term meant "sole ruler," that is, independent ruler, not a ruler with unlimited authority, but obviously the meaning of "unlimited ruler" could not apply to the son of the tsar who did not even sit on the throne and did not "rule." Therefore, Filuishkin concludes, in these cases the title meant a high status but less than that of tsar held by Tsarevich Ivan's father. ${ }^{15}$

4 Filiushkin's explanation is not convincing because the title "autocrat" had no meaning in Tatar politics. As a "tsarevich," the son of a tsar, Tsarevich Ivan already possessed an eminent status, because, certainly in Muscovite eyes, his own dynasty was implicitly equal to that of Chinggis. ${ }^{16}$ The Muscovites knew how to translate their own political terminology into vocabulary comprehensible to the Tatar world. In the very same epistle of 1564 Tsarevich Ivan called himself not only "autocrat" but also "heir" (naslednik), thus establishing his status equality with the Crimean heir, the kalga. ${ }^{17}$ Once a ruler Tsarevich Ivan would have the same status as his father, which was not at issue in this epistle any more than the future status of the kalga as khan of Crimea. Consequently I find the attribution of the title "autocrat" to Tsarevich Ivan superfluous and unmotivated. As Tsarevich Ivan's first usage of "autocrat" occurred before the establishment of the oprichnina in 1564, it is unlikely that there was any connection.

5 According to Filiushkin, Ivan-père started using the title "autocrat" in the 1570s, not, as earlier, as an honorific, but actually as a title. On 2 March 1573 Ivan used the designation in an epistle to the Rada (royal council) of the Polish-Lithuanian Commonwealth and on 1576 to the Holy Roman Emperor. ${ }^{18}$ Such usage remained inconsistent. Filiushkin provides no explanation of Ivan's innovation in his titles in 1573 and 1576. As the oprichnina had been abolished in 1572, there would seem to have been, again, no connection. In May 1571 the Crimean Tatars burned Moscow, a devastating and embarrassing blow to Muscovite prestige widely known in European court and diplomatic circles. Ivan may have invoked 
the meaning of "autocrat" as "independent ruler" to emphasize that he continued to rule his realm as a sovereign, especially after he regained confidence with the defeat of the Crimean Khan in 1572 at Molodi. Filiushkin did not date the 1576 epistle to the Holy Roman Emperor to a month but a great deal was going on at the time. Until September 1576 Simeon Bekbulatovich, a converted Chinggisid, sat on the throne of Moscow as "Grand Prince of All Rus"" while Ivan satisfied himself with the title "Muscovite Prince."19 The Habsburg Court knew this from their ambassador Daniel Printz. In addition, Ivan and the Emperor were actively negotiating who should become the next King of Poland and Grand Prince of Lithuania and how to partition the Commonwealth. It was hardly rare for Ivan to change his title but nearly always he did so by the addition of a recently conquered territory (Kazan', Astrakhan', Sibir', Polotsk/Polatsk and Livonia were all added to Ivan's official title during his reign), but adding "autocrat," usually acquired via coronation, was something else. Consequently Ivan's motive for his self-description in official titulature as "autocrat" remains speculative, but its meaning is not. It meant an independent ruler.

6 Filiushkin's chronology of Ivan's official usage of the title "autocrat" must be amended. Ivan did use the title "autocrat" once before the 1570s. In May 1555 Ivan and Metropolitan Makarii jointly issued instructions to the newly-designated Archbishop of Kazan' Gurii, and Ivan called himself "Tsar and Grand Prince Ivan Vasil'evich of All Rus', Autocrat." Ivan issued an accompanying decree to Gurii in his own name alone which did not repeat the title of his joint decree with "autocrat." ${ }^{20}$ Nevertheless the 1555 decree was official from the state point of view, even if it was an outlier. In all likelihood Ivan's usage of "autocrat" was connected to Church usage of the term, discussed below, at a moment of close Church-State harmony on policy.

7 Nor did Filiushkin cite the excerpt (vypiska) from the diplomatic books of Russian relations with Poland-Lithuania from 1487 to 1572 which declared that in 1572 Ivan's title in his diplomatic epistles included Smolensk, Polotsk and Livonia, and in addition he had added "autocrat." ${ }^{21}$ The narrative summary did not reproduce the actual epistle, which may not survive, but it cannot have been referring to the epistles of 1573 and 1576 which were not yet written.

8 In some nether region between official state titulature and purely rhetorical literary texts stand children's helmets commissioned for young royal boys. Vasilii III had one prepared for Ivan IV circa 1533 when Ivan IV was three. Ivan IV in turn continued the tradition and had one prepared for Tsarevich Ivan in 1557 when Tsarevich Ivan was three, not a coincidence. Both bear inscriptions. In the former Vasilii III described himself with the title "autocrat," in the latter Ivan IV followed suit and described himself as "autocrat."22 Because "autocrat" was not part of Ivan's official title, one would not expect to find it in the law code (Sudebnik) of 1550, Ivan's decrees or his testament, and one would not. In official state titulature, "autocrat" meant an independent, sovereign ruler. ${ }^{23}$

\section{"Autocrat" as a "Pious Ruler"}

Infrequently in official church documents but more often in unofficial discourse by or to clerics than in official state or church documents the word "autocrat" denoted not necessarily an independent ruler but one who governed in accordance with the Orthodox Christian theory that the state and church should act in harmony or symphony, that is 
that they should cooperate for the benefit and propagation of the faith and the maintenance of religious morality. Such an "autocrat" was a pious ruler. When Metropolitan Makarii addressed Ivan after his coronation as "autocrat" and the chronicle narrative described him with that title when he exited the Dormition Cathedral (Uspenskii sobor) these literary embellishments conveyed rhetorical, not legal, significance. ${ }^{24}$ Ivan was being lauded as a proper Orthodox Christian ruler.

11 The official Church "Council of the One Hundred Chapters" (Stoglav) from 1551 accorded Ivan the title "autocrat" in a form which accurately anticipated future usage, "Sovereign Tsar and Grand Prince of All Rus' [or Rosiia]. Autocrat" (gosudar' tsar' i velikii kniaz' Ioann Vasil'evich vseia Rusi / Rosii samoderzhets). ${ }^{25}$ In the ordo for the installation of a metropolitan approved by Ivan and the Holy Council in 1564, coincidentally the year Tsarevich Ivan accorded himself the title "autocrat," Ivan referred in his speech to the "autocracy of the Russian tsardom" (samoderzhst'vo rossiiskago tsarstviia and samoderzhavnoe rossiisskoe tsarstvie). ${ }^{26}$ Ivan was also called "autocrat" in the Psalter which was printed at Aleksandrovskaia Sloboda in 1576-1577 and in corrections to the printed liturgical "Book of Hours" (Chasovnik). ${ }^{27}$ Posthumously the Church officially accorded Ivan the title "autocrat" on his plinth in the Archangel Cathedral (Arkhangel 'skii sobor). ${ }^{28}$

12 Metropolitan Makarii's testament in documentary form was a private, not an official Church, source, and the quotation or probably paraphrase of that document in the so-called "Supplement" to the Nikon Chronicle, actually the Aleksandro-Nevskii Chronicle, should be treated as an unofficial narrative source. Makarii began by referring to Ivan's father, Grand Prince Vasilii III, as an "autocrat" and then addressed Ivan IV as "autocrat" three times. ${ }^{29}$

Chronicles did not consistently employ the title "autocrat" for Ivan. The "Little Chronicle of the Beginning of the Tsardom" (Letopisets nachala tsarstva), which covered the years 1533-1553, described Ivan as "autocrat" in a variety of formats. The word "autocrat" showed up both in the middle and at the end of the title..$^{30} \mathrm{~A}$ "tale" about the "taking" of Kazan' in 1552 alluded to Ivan as "autocrat." 31 The "Book of Degrees of Imperial Genealogy" (Stepennaia kniga tsarskogo rodosloviia) rewrote East-Slavic history by describing all Riurikid rulers from St. Vladimir on as "autocrats" and particularly accorded Ivan the title. ${ }^{32}$ The "Tsar's Book" (Tsarstvennaia kniga), the Lebedev Chronicle and the Aleksandro-Nevskii Chronicle from the Illustrated Chronicle Compilation (Litsevoi letopisnyi svod) appear, at first glance, not to have employed the word frequently or at all in their original passages; nearly all occurrences turn out to be in derivative passages from earlier chronicles or in quoted documents from or to clerics. The title of "autocrat" was not invoked at all in the interpolations on Ivan's 1553 illness or in the narration of the creation of the oprichnina in 1564-1565. Usage of the term in the Illustrated Chronicle Compilation family of chronicles deserves further study. ${ }^{33}$ The absence of a uniform chronicle attitude toward the title suggests the possibility that its occurrence in Makarii's "Testament" might be genuine because it was included in a chronicle which otherwise did not generally attribute the title "autocrat" to Ivan.

14 Addressing Ivan as "autocrat" or referring to him by that title appears to have been fairly widespread although far from mandatory among clerical writers before, during and after Ivan's reign. ${ }^{34}$ Undoubtedly it was in part a form of flattery, a respectful form of address, an honorific, as is obvious from the fact that it was used for rulers who were not crowned as "autocrat." Metropolitan Zosima had accorded Ivan III (Ivan the Great, Ivan IV's 
grandfather) that honor. ${ }^{35} \mathrm{~A}$ funerary laud to Vasilii III already praised him as "autocrat." ${ }^{36}$ The "Epistle of Spiridon-Savva," a precursor to the "Tale of the Princes of Vladimir" (Skazanie o kniaz'iakh vladimirskikh) written by a cleric before 1533, and the "Tale" itself invoked the concept of "autocracy." Its legendary genealogy tracing Ivan IV's ancestry through Riurik to Prus, brother of Augustus Caesar, became the source of much Muscovite written and artistic ideology during Ivan's reign. This text called the realm of Vladimir Monomakh, who supposedly received imperial regalia from the Byzantine Emperor Constantine Monomakh, "a free autocratic tsarstvo" (vol'noe samodr"zhavnoe tsarstvo). ${ }^{37} \mathrm{~A}$ book donation to the Iosifov Monastery lauded Ivan as "autocrat" in 1535, a dozen years before his coronation..$^{38}$ Maksim Grek addressed Ivan as "autocrat" and referred to him with that title in an epistle to the priest Sylvester. ${ }^{39}$ Sylvester himself referred to Ivan as "autocrat" in his epistle to Prince Aleksandr Borisovich Gorbatyi-Shuiskii. ${ }^{40}$ Circa 1550 Metropolitan Makarii addressed Ivan as "autocrat" in Makarii's spirited defense of the inalienability of ecclesiastical and monastic landowning and property in the face of a supposed threat of secularization. ${ }^{41}$ At approximately the same time Archbishop Feodosii of Novgorod wrote a letter to Makarii in which Feodosii referred to Ivan as "autocrat." ${ }^{42}$ The "tale" of Feodosii's death in 1563, written by his cell-mate the monk Eufimii, called Ivan "autocrat" four times. ${ }^{43}$ In the middle of the sixteenth century the Volokolamsk Paterikon described Grand Prince Vasilii II in the middle of the fifteenth century as "autocrat." ${ }^{44} \mathrm{~A}$ laud (more like a toast) to Ivan composed by an unknown cleric circa 1558 accorded him the title "autocrat." ${ }^{45}$ The vita of Kassian Bosoi written in the 1550s-1560s called Ivan III "autocrat." ${ }^{\text {" }}$ A toast (chasha) to Ivan circa 1561-63 also included "autocrat" in Ivan's title..$^{47}$ The vita of Kornilii Komel'skii written in the last quarter of the sixteenth century described Vasilii III as "an autocratic sovereign" (samoderzhavnyi gosudar'). ${ }^{48}$ The vita of Antonii Siiskii written 1578 called Vasilii III "autocrat" twice but also honored Ivan the same way. The colophon by the priest-monk Iona recounted that the vita was written in the "autocratic tsarstvo of Tsar and Grand Prince Ivan Vasil'evich of Kiev, Moscow and All Rus', Autocrat" and later used an informal version of Ivan's title with "autocrat." ${ }^{49}$ The funerary laud (pokhval'noe slovo) to Saint Antonii Siiskii written circa 1579 by Tsarevich Ivan Ivanovich called his father Tsar Ivan "autocrat." ${ }^{50}$ Such allusions contemporary to Ivan's reign could be multiplied even further. ${ }^{51}$ The ubiquity of such references in largely clerical literature stands out.

There were two cases in which Ivan's mother, Grand Princess Elena Glinskaia, was exalted with the feminine form of the word "autocrat" (samoderzhitsa) during her first-born son's reign: first during her lifetime, in the redaction of the vita of Mikhail Klopskii written by boyar Vasilii Mikhailovich Tuchkov for the "Great Menology" of then Archbishop of Novgorod Makarii in 1537 (Elena died in 1538), and second posthumously, in the "Book of Degrees" where she was described as the "autocratic ... spouse" (samoderzhavnaia ... supruga) of Vasilii III. ${ }^{52}$ No doubt the meaning here was also "pious" because officially only the minor Ivan reigned, so she could not be "independent."

The title "autocrat" also cropped up in reference to Ivan in chronicles and other narratives written after his death..$^{53}$ It is no surprise that the "Kazan' History" (Kazanskaia istoriia), which may have been written during Ivan's reign but all of whose manuscripts derive from a post-Ivan redaction, called Ivan (and some of his predecessors) "autocrat." ${ }^{54}$ The 1590s redaction of the Vita of Aleksandr Nevskii by archbishop Iona accorded Ivan that title. ${ }^{55}$ But the earliest 1590s redaction of the vita of Metropolitan 
Filipp disrespected Ivan; it called Vasilii III "autocrat" once but never Ivan. ${ }^{56}$ After the "Time of Troubles" (Smutnoe vremia) Avraamyi Palitsyn allocated the title "autocrat" to Ivan, a practice perpetuated in 1692 by Andrei Lyzlov. ${ }^{57}$ Late seventeenth-century manuscripts of the vita of St. Trifon of Pechenga followed suit..$^{58}$ Post-1584 manuscripts of hymns called St. Vladimir "autocrat" and referred to Ivan as "autocrat" when naming him composer of a hymn..$^{59}$ Undoubtedly additional seventeenth-century witnesses could also be located.

Despite the quantity of these examples, narratives and ecclesiastical sources during Ivan's reign did not uniformly accord Ivan the title of "autocrat." The "Tale of Stefan Batory's Attack on Pskov" (Povest' o prikhozhdenii Stefana Batoriia na grad Pskov) written by an icon-painter, for example, did not. ${ }^{60}$ Therefore, describing Ivan as "autocrat" meaning "pious ruler" was not normative for the Russian Orthodox Church, merely popular. As we shall see, clerics were not of one mind on the meaning of "autocrat" either.

"Autocrat" also showed up, widely enough but hardly ubiquitously, in sixteenth-century literature to refer to rulers other than members of the Moscow dynasty. For example, the princes of Murom in the "Tale of Petr and Fevroniia" by the priest-later monk Ermolai-Erazm received the title. ${ }^{61}$ Ivan Peresvetov, however, used the title only once, and to refer to Vasilii III at that. ${ }^{62}$ These occurrences of the title usually "autocrat" lacked explication of any sort. The meaning of the title was considered self-evident. From the clerical or religious context I have inferred that the word denoted a pious ruler. Obviously an impious ruler could not be addressed with respect by a cleric. An "autocracy," we may infer, was a realm in which the ruler and the church cooperated harmoniously. Maksim Grek, although he was applying classical literature, defined a true "autocrat" as one who had conquered lust, ambition and greed. In his letter to Ivan Maksim recommended that he acquire the virtues of philanthropy, goodness, meekness, and justice. ${ }^{63}$ The autocrat Prince Petr of Murom was praised for his humility and mercy, and lack of "fierceness" (iarost'). ${ }^{64}$ Maksim and Ermolai-Erazm would seem to have been arguing with an alternative definition of "autocrat" which identified the domestic characteristics of an autocrat differently than those they advocated. Ermolai-Erazm was describing a prince, not a tsar. Although Maksim was addressing an independent ruler, by no means would a ruler have to be independent to follow Maksim's dictums.

Although Maksim Grek and the state secretary (d'iak) Fedor Karpov did not always see eye to eye, Karpov's exposition of the obligation of an "autocrat" seems compatible with Maksim's. In his epistle to Metropolitan Daniil Karpov wrote that the political leader (nachal'nik) of an "autocracy" (samoder" zhstvo) brings sinners to agreement with the righteous by his "awesomeness" (groza) in implementing justice (pravda) and legality (zakon), just as a harpist unites the sounds of his strings in harmony. Many political leaders neglect to succor orphans and those in need ; ruling requires justice and mercy. ${ }^{65}$ Again, Karpov defined an "autocrat" in terms of his obligation to domestic policy, which does not fit the "sovereignty" model. ${ }^{66}$ Maksim Grek, Ermolai-Erazm, and Karpov, by describing the virtues of an autocrat, expressed views consistent with the meaning of "autocrat" as a pious ruler, although with different emphases. Ermolai-Erazm's characterization of Petr of Murom stands apart because he was a saint. 


\section{"Autocrat" as an "Unlimited Ruler"}

21 The meaning of "autocrat" against which so many clerics implicitly and Maksim Grek and Karpov explicitly seemed to be arguing was that of an unlimited ruler. This meaning can be found in the "Discussion of the Valaam Wonder-Workers Sergii and German" (Beseda valaamskikh chudotvortsev Sergiia i Germana), commonly denoted simply as the "Valaam Discussion" (Valaamskaia beseda). This text purported to be of monastic origin but its conception of an autocrat violated that of the clerical authors discussed so far. The tsar holds the title of "autocrat" (samoderzhets) (which Ivan did not) but he cannot be an "autocrat" if he does not decide policy by himself. If he consults friends, princes and boyars, and especially monks, he is not an "autocrat." ${ }^{67}$ A ruler who need not consult anyone in formulating policy would have to be independent so the third definition of "autocrat" subsumes the first, an independent ruler, but such a ruler could not cooperate with the Church in applying Orthodox Christianity to domestic policy as implied by the second definition. Elevating the ruler's absolute authority in this way topples the exaltation of consultation as an obligatory element of the behavior of the ruler very widespread in Muscovite discourse. ${ }^{68}$ It seems counter-intuitive for monks to have composed a critique of monks as "unburied corpses" but a monk who objected to monks participating in secular affairs might have done so. Unfortunately the question of the authorship of the "Valaam Discussion" cannot be answered definitively.

Light on the question of the origin of the third definition of "autocrat" comes from Prince Andrei Kurbskii's "History of the Grand Prince of Moscow" (Istoriia o velikom kniaze Moskovskom). Kurbskii reported a probably apocryphal discussion between Bishop Vassian Toporkov and Ivan in which Toporkov reputedly said: "If you wish to be an autocrat, do not keep beside you a single councillor wiser than yourself, for you are better than all." If Ivan kept wiser men at his side, Ivan would be dependent upon them for advice. ${ }^{69}$ If Kurbskii did not make this story up, which is possible, then he was likely regurgitating gossip circulating in Muscovy and among Muscovite emigres which defined an "autocrat" as someone who did not need to take advice from anyone. Of course, if Ivan should not take advice from anyone wiser than himself, then he could not take advice from Toporkov unless Toporkov was less wise than Ivan, in which case why would Ivan want to take advice from him? This kind of logical analysis is too logical for sixteenth-century Muscovite polemics. More to the point, that Ivan was identified as an "autocrat" in this vignette was secondary in Kurbskii's own estimation. When Kurbskii recounted the same episode in his Third Epistle to Ivan, his summary did not mention an "autocrat," just a ruler. ${ }^{70}$ Kurbskii's focus was on advice, good or bad, from advisors, good or evil, not on autocracy.

23 It is impossible to demonstrate that Ivan read the "Valaam Discussion" but Ivan's "First Epistle to Kurbskii" shared the same conception of the ideal authority of the "autocrat." "But as for the Russian autocracy (samoder'zhstvo), they themselves [i.e. the autocrats] have ruled all their dominions, and not the boyars and not the grandees (vel'mozhi)." "How, pray, can a man be called autocrat (samoderzhets) if he himself does not govern?"

${ }^{72}$ The thrust of Ivan's First Epistle was ironically to malign Ivan's own decision-making authority during his minority and the period of "reforms." Regardless of the accuracy of this polemical argument, Ivan clearly invoked the concept of "autocrat" as alone possessing the power to set policy. An "autocrat" was ruler of an "autocracy." It is a bit 
unexpected, however, that among the corpus of Ivan's epistles other than his "First Epistle to Kurbskii," references to "autocracy" appeared only in two epistles ghostwritten by Ivan to Sigismund Augustus II, King of Poland and Grand Prince of Lithuania, in the names of Princes Ivan Bel'skii and Mikhail Vorotynskii which described Ivan's "free autocracy" (volnoe samoderzh'stvo). ${ }^{73}$ Ivan undoubtedly thought of himself as a pious and sovereign ruler with unilateral decision-making authority but he only infrequently articulated those characteristics by claiming the title "autocrat."

Ivan's usage of the title "autocrat" leads to two conclusions. First, Ivan understood all three meanings of the term elucidated in this article, independent ruler, pious ruler and unlimited ruler. Second, the concept of "autocrat" was not very important to Ivan or Ivan's theory of imperial authority. The rarity of Ivan's references to it cannot be explained away simply by the reality that "autocrat" was not part of Ivan's coronation title. The concept was readily available in Muscovite political discourse. It must have been known to the Court to show up at all in official government diplomatic correspondence. official Church and unofficial Church and lay usage of the term was part of the environment of the Court and its elite. When Ivan wanted to use "autocrat," he did so, and the absence of the title in his coronation in no way precluded his invoking it, as he did rarely, in his or Tsarevich Ivan's official diplomatic correspondence, not always with an understandable motive, and in Ivan's political discourse. However it is entirely indicative of the weight of the concept of "autocrat" in sixteenth-century Muscovite political consciousness that the term did not appear in Kurbskii's epistles or more than once in his "History of the Grand Prince of Moscow." "The variation in where the word "autocrat" was placed in Ivan's title in discourse, not always at the end of his title as became standard, reflected, I think, the very fact that "autocrat" was not part of Ivan's official titulature which would have mandated where the word should be sequenced. Similarly only one text not by Ivan of purported clerical origin, the "Valaam Discussion," expressed the unlimited-ruler meaning of "autocrat."

The relative insignificance of the concept of "autocrat" to Ivan in any meaning, despite its general availability, requires explanation. Why did Ivan think that he did not need to accord himself the title "autocrat" ? The short answer is, because he was tsar. ${ }^{75}$ The bedrock of Ivan's conception of ruler was his coronation as "tsar." Ivan was the God-ordained, God-selected, God-crowned and God-protected tsar. He was superior to rulers of base origin such as Erik XIV of Sweden, to elected rulers such as Stefan Batory and again the Kings of Sweden (and maybe even the Holy Roman Emperor), to rulers who were compelled to consult their merchants such as Elizabeth I of England. Ivan was pious, sovereign and possessed unlimited authority "to reward and to punish" as tsar; he did not need to claim to be "autocrat" to acquire any or all of these attributes. ${ }^{76}$ From this perspective Ivan was not crowned "autocrat" and did not claim very often to be "autocrat" because he did not need to be crowned "autocrat" or proclaim himself "autocrat." The marginal value of the concept of "autocrat" in Ivan's own writings impugns assertions in scholarship that Ivan thought of himself as ruler primarily as an "autocrat." Ivan rarely used the word "autocrat" because he did not need the concept "autocrat" to express his ideology.

Ivan's official usage, however rare, of "autocrat" to apply to himself or Tsarevich Ivan also invalidates the invocation of that concept to explain the oprichnina. The chronology of the appearance of the term betrays no connection to the oprichnina. It is therefore highly unlikely that Ivan intended the oprichnina as an instrument to implement genuine 
"autocracy" or as the practical application of "autocracy," or that the goal of the oprichnina was to establish "autocracy" for real or that the oprichnina constituted an attempt to implement the "unlimited autocratic ideal." 77 The purpose of the oprichnina must lie outside the domain of the title "autocrat" or the theory of "autocracy."

It is plausible to suggest that the term "autocrat" gained currency during Ivan's reign because, although Ivan was not crowned "autocrat," his son and successor Tsar Fedor Ivanovich was. $^{78}$

In official usage under Ivan an "autocrat" meant an independent ruler, which would probably have applied to his son's official title. In unofficial discourse during Ivan's reign but not written by him an "autocrat" most often seems to have meant a pious ruler. Ivan used the term to mean "unlimited ruler" infrequently at best. Historians who used the term "autocracy" to mean a state with an unlimited ruler are referencing the least current meaning of the term during Ivan's reign. Historians who discussed Ivan's theory of "autocracy" were elevating a minor theme in his writings to a level of importance it did not merit. Of course historians can still refer to Muscovy during Ivan's reign as an "autocracy" meaning a state with an unlimited ruler as long as they qualify that meaning of "autocracy" as relatively unimportant to contemporaries. However it might be prudent for specialists in Muscovite history at least to cease and desist from referring to Ivan's "theory of autocracy" and instead to utilize a more neutral phrase which better fits Ivan's ideological priorities, such as Ivan's "theory of tsardom." Ivan was a tsar first and an autocrat only second. As tsar Ivan possessed the same authority that he ascribed to an autocrat and that historians identified as those of an autocrat. For this reason describing Muscovy as a tsardom, not an autocracy, better accords with Ivan's own perceptions.

The word tsar' translated the title of the Byzantine basileus, the Mongol khan, and Biblical Kings of Israel Solomon and David, and tsarstvo denoted an empire and a kingdom. The polysemanticism of Muscovite thought applied to tsar/tsarstvo as much as it did to autocrat/autocracy. Of course the title "tsar" and the term "tsarstvo" require further study, which is beyond the limits of this article.

\section{NOTES}

1. Natalia Pushkareva with Eve Levin, Women in Russian History: From the Tenth to the Twentieth Century (Armonk: M.E. Sharpe, 1997), 67, refer to Ivan before 1538 as the "young autocrat."

2. Vasilii Osipovich Kliuchevskii, Sochineniia [Works] tom II, Kurs russkoi istorii [Course of Russian History] chast' 2 (M.: Gosudarstvennoe izdatel'stvo politicheskoi literatury, 1957), 168-169.

3. Mikhail D'iakonov, Vlast' Moskovskikh gosudarei: Ocherki iz istorii politicheskikh idei Drevnei Rusi do kontsa XVI veka [The Authority of the Muscovite Sovereigns: Studies in the History of Political Ideas in Ancient Rus'] (SPb. : Tipografiia I.N. Skorokhodova, 1889 ; Slavistic Printings \& Reprintings, \#159; The Hague - Paris : Mouton, 1969), 158-160. 
4. Ruslan Grigor'evich Skrynnikov, Tsarstvo terrora [Reign of Terror] (SPb.: Nauka, Sankt-Peterburgskoe otdelenie, 1992), 86, 100, 126, 170, 210, 261, 311, 404, 523, 524.

5. Victor Leontowitsch, Die Rechtsumwälzung under Iwan dem Schrecklichen und die Ideologie der Russischen Selbstherrschaft (Stuttgart : F.F. Koehler Verlag, c. 1947) ; Helmut Neubauer, Car und Selbstherrscher: Beiträge zur Geschichte der Autokratie in Rußland (Wiesbaden: Otto Harrassowitz, 1964); Sigurd Ottonovich Shmidt, Stanovlenie rossiiskogo samoderzhavstva: Issledovaniia sotsial'no-politicheskoi istorii vremeni Ivana Groznogo [The Establishment of Russian Autocracy : Investigations of the Social-Political History of the Time of Ivan the Terrible] (M. : Mysl', 1973); Daniil Natanovich Al'shits, Nachalo samoderzhaviia v Rossii : Gosudarstvo Ivana Groznogo [The Beginning of Autocracy in Russia: The State of Ivan the Terrible] (L.: Nauka, Leningradskoe otdelenie, 1988); Alexander Dvorkin, Ivan the Terrible as a Religious Type : A Study of the Background, Genesis and Development of the Theocratic Idea of the First Russian Tsar and his Attempts to establish "Free Autocracy" in Russia. Forward John Meyendorff (Erlangen: Lehrstuhl für Geschichte und Theologie, 1992); Margarita Evgen'eva Bychkova, Moskovskie samoderzhtsy. Istoriia vozvedeniia na prestol: Obriady i regalii [Muscovite Autocrats: The History of the Installation on the Throne. Rituals and Regalia] (M.: Institut Rossiiskoi istorii RAN, 1995); V.A. Kolobkov, Mitropolit Filipp i stanovlenie moskovskogo samoderzhaviia, Oprichnina Ivana Groznogo [Metropolitan Philip and the Establishment of Muscovite Autocracy : The Oprichnina of Ivan the Terrible] (SPb. : Ateleiia, 2004).

6. "Facade" school : Nancy Shields Kollmann, Kinship and Politics : The Making of the Muscovite Political System, 1345-1547 (Stanford : Stanford University Press, 1987).

7. On the distinctions among official state documents, official church documents, mixed official documents, and unofficial texts see Charles J. Halperin, "What Is an 'Official' Muscovite Source From the Reign of Ivan IV ?" in Ann M. Kleimola, Gail Lenhoff, eds., The Book of Royal Degrees and the Genesis of Russian Historical Consciousness / "Stepennaia kniga tsarskogo rodosloviia" $\mathrm{i}$ genezis russkogo istoricheskogo soznaniia (Bloomington : Slavica Publishers, Inc., 2011), 81-93.

8. Despite Paul Bushkovitch, "The Formation of National Consciousness in Early Modern Russia," Harvard Ukrainian Studies 10 (1986) : 355-376, here 368 n. 17, 374 n. 24 that it had only one meaning in the sixteenth century. The best discussion of the multiple meanings of samoderzhavie in sixteenth-century Muscovy remains Vladimir Val'denberg, Drevnerusskiia ucheniia o predelakh tsarskoi vlasti: Ocherki russkoi politicheskoi literatury ot Vladimira Sviatogo do kontsa XVII veka [Ancient Russian Teachings on the Limits of Tsarist Authority: Studies of Russian Political Literature from St. Vladimir to the End of the Seventeenth Century] (Petrograd: A. Benke, 1916; Russian Reprint Series XXII ; The Hague : Europe Printing, 1966), introductory remarks 1, 13, 442-44. (Pages on specific writers will be cited below.)

9. Elpidifor V. Barsov, "Drevne-russkie pamiatniki sviashchennago venchaniia tsarei na tsarstvo s sviazi s grecheskimi ikh originalami. S istoricheskim ocherkom chinov tsarskago venchaniia $\mathrm{v}$ sviazi s razvitiiem idei tsaria na Rusi [Ancient Russian monuments of the holy coronation of tsars on the kingdom in connection with their Greek originals. With an historical account of the ritual of coronation in connection with the development of the idea of Tsar in Rus']," Chteniia v Imperatorskom Obshchestve istorii $\mathrm{i}$ drevnostei rossiiskikh pri Moskovskom universitete [Readings in the Imperial Society of History Russian Antiquities at Moscow University] [hereafter Chteniia] 1883 kniga 1, otd. I, tom 124, I-XXXV, 1-160, here 42-90, despite Vasilii Nikitich Tatishchev, Istoriia Rossiiskaia [Russian history], v. 6 (M.-L. : Izdatel'stvo A.N. SSSR, 1966), 162.

10. Sobranie gosudarstvennykh gramot i dogovorov, khraniashchikhsia v Gosudarstvennoi Kollegii inostrannykh del [Collection of State Charters and Treaties, preserved in the State College of Foreign Affairs] vol. II (M. : Tipografiia N.S. Vsevolozhskago, 1819), no. 51, 72-85.

11. Sergei Mikhailovich Kashtanov, Iz istorii russkogo srednevekovogo istochnika. Akty X-XVI vv. [From the History of the Russian Medieval Source. Acts of the X-XVI centuries] (M. : Nauka, 1996), 117 ; idem, ed., Rossiia i grecheskii mir v XVI veke [Russia and the Greek World in the XVI Century] 
Tom I (M. : Nauka, 2004), 37 ; and Marc Szeftel, "The Title of the Muscovite Monarch up to the End of the Seventeenth Century," Canadian-American Slavic Studies 13 (1979) : 59-81, here 66, erred in asserting that Ivan never used the title "autocrat." The use of "autocrat" in correspondence to Ivan from the Serbian Hilandar Monastery on Mt. Athos does not count: M. Dmitrijevich, ed., "Dokumenti koji se tichu odnosa izmefu srpske tsrkve i Rusije v XVI veku [Documents concerning the relations between the Serbian church and Russia in the XVI century]," Spomenik, Srpska kralevska akademija [Memorial, Serbian Royal Academy] 39 (1903), 16-42, here \#21, 27-31, 1558.

12. It is of course possible that the title occurred elsewhere in unpublished Muscovite diplomatic documents that Filiushkin either did not consult or missed.

13. Filiushkin did not cite Prince Mikhail Shcherbatov, Istoriia rossiiskaia ot drevneishikh vremen [Russian History from the Most Ancient Times] volume V part IV (SPb. : Imperatorskaia Akademiia Nauk, 1789), 43-47, which appears to be the October 1564 epistle of Tsarevich Ivan.

14. Tsarevich Ivan was born in March, 1554, so he was twelve-fourteen years old at the time of this correspondence.

15. Aleksandr Il'ich Filiushkin, Tituly russkikh gosudarei [The Titles of Russian Sovereigns] (M. SPb.: Al'ians-Arkheo, 2006), 55-59 citing RGADA (Rossiiskii gosudarstvennyi arkhiv drevnikh aktov) f. 123, op. 1, d. 11, 1. 144 ob ; d. 12, 1. 144.

16. This is a complicated issue because Chinggisid rulers rarely accorded Ivan a title equivalent to "khan." See Charles J. Halperin, "Ivan IV and Chinggis Khan," Jahrbücher für Geschichte Osteuropas [hereafter JbfGOE] 51 (2003) : 481-497.

17. Filiushkin, Tituly russkikh gosudarei, 95 . Filiushkin confusingly discussed these two aspects of this epistle separately. Tsarevich Ivan invoked his status as "heir" again in another epistle to Mukhammed Girei in July 1565. As far as I know these articulations of the status of "heir" were unique. In the "Tsar's Book" (Tsarstvennaia kniga) "The Tale of the Death of Vasilii III" described Ivan IV as his father's "heir" (Polnoe sobranie russkikh letopisei [Complete Collection of Russian Chronicles] [hereafter PSRL] 13, 412) but also the "oldest" (stareishii) son (ibid., 415). I am not convinced by Sergei Bogatyrev, "Micro-Periodization and Dynasticism : Was There a Divide in the Reign of Ivan the Terrible ?" Slavic Review, 69 (2010) : 398-409 here 404 and idem, “Dinastiia kak faktor razvitiia rossiiskogo gosudarstvo $\mathrm{v}$ XVI veke [The dynasty as a factor in the development of the Russian State in the XVI century]," in Gyula Szvák, ed., Rol' gosudarstva v istoricheskom razvitii Rossii / The Role of the State in the Historical Development of Russia (Budapest : Russica Pannonicana, 2011), 68-79, here 71 that the Formulary Redaction of Ivan's 1547 coronation ordo, composed circa 1565-70, in which his father, Grand Prince Vasilii III, called Ivan (IV) his "first" (pervyi, interpreted as "first-born") son constituted an official proclamation of Tsarevich Ivan's status as heir apparent by setting a precedent. If Tsarevich Fedor Ivanovich could not be called Ivan IV's "first son" in his 1584 coronation (Isaiah Gruber, Orthodox Russia in Crisis : Church and Nation in the Time of Troubles (DeKalb: Northern Illinois University Press, 2012), 77), then neither could Tsarevich Ivan have been depicted as "first son." Ivan IV's only "first son" was the first Tsarevich Dmitrii (son of Tsaritsa Anastasiia). In Tatar the son of a khan was a "sultan," translated into Russian as "tsarevich," son of a tsar / khan, not to be confused with the title of the ruler of the Ottoman Empire who was neither a Chinggisid nor a khan.

18. Filiushkin, Tituly russkikh gosudarei, 62-63, 1572: OR RGB f. 304 (Trinity collection), dop. II, No. 17, 1. 189 ob, with copies in RGADA f. 79, op. 1, reestr, 2, No. 1, 1. 4 and OR RGB, f. 235, papka 3, d. 21, 1. 9 ; 1576 : RGADA f. 32 (Austrian affairs), op. 1, stolbtsy, d. 1, 1. 1.

19. Donald Ostrowski, "Simeon Bekbulatovich's Remarkable Career as Tatar Khan, Grand Prince of All Rus', and Monastic Elder," Russian History, 39 (2012) : 269-299 ; Alexander Filjushkin, "The Mystery of a Political Masquerade (Concerning the Article of Donald Ostrowski)," ibid., 301-305 ; Charles J. Halperin, "Simeon Bekbulatovich and the Mongol Influence on Ivan IV's Muscovy," ibid., 306-30 ; Janet Martin, "Simeon Bekbulatovich and Steppe Politics: Some Thoughts on 
Donald Ostrowski's Interpretation of the Tsar's Remarkable Career," ibid., 331-338; and Ostrowski, "Response," ibid., 339-345.

20. Akty sobrannye $\mathrm{v}$ bibliotekakh i arkhivakh Rossiiskoi imperii Arkheograficheskoiu Ekspeditsieiu Imperatorskoi Akademii Nauk [Acts collected in the libraries and archives of the Russian Empire by the Archeographic Commission of the Imperial Academy of Sciences] [hereafter AAE], Tom pervyi 1294-1598 (SPb.: Tipografiia II otdeleniia sobstvennoi E.I.V. Kantseliarii, 1836), 257, 261.

21. S.O. Shmidt, ed., "Vypiska iz posol'skikh knig" o snosheniiakh Rossiiskogo gosudarstva s Pol 'sko-Litovskim za 1487-1572 ["Extract from the Diplomatic Books" on relations of the Russian State with Poland-Lithuania during 1487-1572] (M. - Warsaw : Arkheograficheskii tsentr, 1997), 273.

22. Sergei Bogatyrev, "Chapter 10. Ivan IV (1533-84)," in Maureen Perrie, ed., Cambridge History of Russia, v. I, From Early Rus' to 1689 (Cambridge : Cambridge University Press, 2006), 240-263, here 243, 251, Plates 12a (Ivan's helmet) and 12b (Tsarevich Ivan's helmet).

23. Isabel de Madariaga, Ivan the Terrible: First Tsar of Russia (New Haven: Yale University Press, 2005), $364+n .1$ concluded that "samoderzhavie" meant only "sovereignty" and denied the existence of any political system called "autocracy."

24. Barsov, "Drevne-russkie pamiatniki sviashchennago venchaniia tsarei na tsarstvo s sviazi s grecheskimi ikh originalami," 74-75 ; PSRL 13 (M. : Nauka, 1965), 151.

25. Stoglav [One Hundred Chapters] (Izdanie D.E. Kozhanchikova ; SPb. : Tipografiia Imp. A.N., 1863 ; Reprint Letchworth, Hertfordshire, England, 1971, Bradda Books Ltd, Rarity Reprints \#17), 19, 58, 59. Cf. Arkhimandrit Makarii (Veretennikov), Iz istorii russkoi ierarkhii XVI veka [From the history of the Russian Hierarchy of the XVI century] (M. : Izdatel'stvo Moskovskogo podvor'ia Sviato-Troitskoi Sergievskoi Lavry, 2006), 222-37, here 222, 227.

26. AAE v. 1, \#264, 297-300, here 299.

27. Psalter : Sergei Fomin, Pravda o pervom russkom tsare: Kto i pochemu iskazhaet obraz Gosudaria Ioanna Vasil'evicha (Groznogo) [The Truth about the first Russian tsar. Who distorts the image of sovereign Ivan Vasil'evich (The Terrible) and Why] (M. : Russkii izdatel'skii tsentr, 2010), 416; "Book of Hours": M.N. Tikhomirov, A.A.Sidorov, A.I. Nazarov, eds., U istokov russkogo knigopechataniia: $\mathrm{K}$ trekhsot-semidesiatipiatiletiiu so dnia smeriti Ivana Fedorova 1583-1958 [At the roots of Russian book-printing: On the $375^{\text {th }}$ Anniversary of the Death of Ivan Fedorov 1583-1958] (M.: Izdatel'stvo A.N. SSSR, 1958), 220 (article on "post scripts" by M.V. Shchepkina); Evgenii L'vovich Nemirovskii, Vozniknovenie knigopechataniia v Moskve : Ivan Fedorov [The beginning of book-printing in Moscow : Ivan Fedorov] (M.: "Kniga”, 1964), 316.

28. Fomin, Pravda o pervom russkom tsare, 260.

29. PSRL 13, 374-77 ; PSRL 29 (M. : Nauka, 1965), 327-329. Anna Leonidovna Khoroshkevich, Rossiia v sisteme mezhdunarodnykh otnoshenii serediny XVI veka [Russia in the system of international relations of the middle of the XVI century] (M. : Drevnekhranilishche, 2003), 389 wrote that Ivan was "no doubt pleased" at this usage by Makarii of a title that Ivan had not obtained in reality.

30. PSRL $13: 80,87,92,109,110$; PSRL $29: 12,14,16,215$. There is no evidence that the "Chronicle of the Beginning of the Tsardom" originated in the Court as is commonly assumed. Isolde Thyrêt, "The Tale of the Death of Vasilii Ivanovich and the Evolution of the Muscovite Tsaritsa's Role in Sixteenth-Century Russia," in Brian J. Boeck, Russell E. Martin, and Daniel Rowland, eds., Dubitando: Studies in History and Culture in Honor of Donald Ostrowski (Bloomington : Slavica Publishers, Inc., 2012), 209-24, here 214 n. 19.

31. A.N. Nasonov, "Novye istochniki po istorii Kazanskogo 'vziatiia' [New sources on the history of the 'taking' of Kazan]," Arkheograficheskii ezhegodnik za 1960 [Archeographic yearbook for 1960] (1962) : 3-26, here 8. 
32. Nikolai Nikolaevich Pokrovskii, G.D. Lenkhoff [Gail D. Lenhoff], eds., Stepennaia kniga tsarskogo rodosloviia po drevneishim spiskam : Teksty i kommentarii. [The Book of Degrees of Imperial Genealogy according to the Oldest Manuscripts: Texts and Commentary] 3 vol. Tom pervyi : Zhitie sv. Kniagini Ol'gi, Stepeni I-X [Volume One: The Life of St. Princess Olga, Degrees I-X] (M. : Iazyki slavianskikh kul'tur, 2007), 215 ; Tom vtoroi : Stepeni XI-XVII, Prilozheniia. Ukazateli [Volume Two : Degrees XI-XVII. Appendices. Indexes (M. : Iazyki slavianskikh kul'tur, 2008), (about Vasilii III :) 286, 315, 318, 321 ; (about Ivan IV :) 344, 327, 374-75, 375, 381, 394 (an epistle from the Patriarch of Alexandria, although Ivan's reply, 298-99 gives Ivan's official title without "autocrat"). On the dating and provenance of this text see Charles J. Halperin, "Stepennaia kniga on the Reign of Ivan IV : Omissions from Degree 17," Slavonic and East European Review, 89 (2011) : 56-75, here 56-57.

33. "Tsar's Book" : PSRL 13, 415 (about Monomakh, the only instance in the "Tale of the death of Grand Prince Vasilii III"), 452 (twice, in Ivan's coronation), 462, 463, 476, 479, 489, 494 (Kazan' conquest) ; PSRL, 29 (Lebedevskaia letopis') copied 236 (but not previous), 270, 273 ; in new annals 306, epistle of Novgorod Archbishop Pimen ; PSRL 29 (Aleksandro-

Nevskskaia letopis'), imitated the "Little Chronicle of the Beginning of the Tsardom" passages which referred to Ivan as "autocrat" beginning with the death of Vasilii III, Ivan's coronation, the conquest of Kazan' 123, 150, 182, but in its original annals only, as far as I have so far found, in Metropolitan Makarii's testament cited above and in Ivan's speech to new Metropolitan Afanasii in 1563 and Afanasii's reply upon his installation 332, 333.

34. According to Szeftel the Church wanted an internal, not just an external, "unrestricted absolute sovereign" but this idea struck no roots in sixteenth-century Muscovy. See Szeftel, "The Title of the Muscovite Monarch," 65-69, quote 69. An internally "unrestricted" ruler would not have been answerable to Church authority concerning the beliefs and practice of the faith. It hardly seems likely that the Church sought such a ruler. See Andrei Vital'evich Karavashkin, Russkaia srednevekovaia publitsistika : Ivan Peresvetov, Ivan Groznyi, Andrei Kurbskii [Russian Medieval Publicistics : Ivan Peresvetov, Ivan the Terrible, Andrei Kurbskii] (M. : Prometei, 2000), 318.

35. Michael S. Flier, "Till the End of Time: The Apocalypse in Russian Historical Experience Before 1500," in Valerie A. Kivelson, Robert H. Greene, eds., Orthodox Russia : Belief and Practice under the Tsars (University Park : Pennsylvania State University Press, 2003), 127-158, here 155.

36. N.N. Rozov, "Pokhval'noe slovo velikomu kniaiziu Vasiliiu III [Laud to Grand Prince Vasilii III]," Arkheograficheskii ezhegodnik za 1964 (1965) : 278-289, here 281.

37. Rufina Petrovna Dmitrieva, Skazanie o kniaz'iakh vladimirskikh [Tale of the Princes of Vladmir] (M. - L. : Izdatel'stvo A.N. SSSR, 1955), 165 ("The Epistle of Spiridon-Savva"), 177 ("Tale of the Princes of Vladimir").

38. Arkhimandrit Makarii, Iz istorii russkoi ierarkhii XVI veka, 242.

39. Maksim to Ivan : Sochineniia prepodobnago Maksima Greka [Works of the Reverend Maksim the Greek] v. 2 (Kazan' : Kazanskaia Dukhovnaia akademiia, 1859), 157, 286, 291, 346 ; v. 3 (1859), 77. Cf. V.F. Rzhiga, "Opyty po istorii russkoi publitsistiki xvI veka. Maksim Grek kak publitsist [Essay on the history of Russian publicistics of the xVI century: Maksim the Greek as a publicist]," Trudy Otdela drevnerusskoi literatury [Works of the sector of Old Russian Literature] [hereafter TODRL] 1 (1934) : 5-120, here 117-19; Maksim to Sylvester : D.P. Golokhvastov and archimandrite Leonid, "Blagoveshchenskii ierei Sil'vestr i ego pisaniia. Issledovaniia [The Blessed priest Sylvester and his epistles. Investigations]," Chteniia 1874 kniga 1, tom 88: 1-107, here 31-32. See Val'denberg, Drevnerusskiia ucheniia o predelakh tsarskoi vlasti, 264.

40. Golokhvastov and Leonid, "Blagoveshchenskii ierei Sil'vestr i ego pisaniia. Issledovaniia," 88-100, here 90. See Val'denberg, Drevnerusskiia ucheniia o predelakh tsarskoi vlasti, 294 n. 2. 
41. Galina Nikolaevna Moiseeva, "Starshaia redaktsiia 'Pisaniia' mitropolita Makariia Ivanu IV“ [The oldest redaction of the "Writing" of Metropolitan Makarii to Ivan IV], TODRL 16 (1960) : 466-472, here 470.

42. Arkhimandrit Makarii, Iz istorii russkoi ierarkhii XVI veka, 205.

43. Ibid., 205-213, here 207 (twice), 208, 209.

44. L.A. Ol'shevskaia, S.N. Travnikov, eds., Drevnerusskie pateriki. Kievo-Pecherskii Paterik. Volokolamskii Paterik [old Russian paterikons. The Kievan-Caves Paterikon. the Volokolamsk Paterikon] (M. : Nauka, 1999), 213.

45. I.D. Azvolinskaia, "Neizvestnyi tekst privetstviia Ivanu Groznomu," [Unknown text of a greeting to Ivan the Terrible] in Pamiatniki kul'tury. Novye otkrytiia. Pis'mennost' Iskusstvo Arkheologiia. Ezhegodnik 1974 [Monuments of culture. New discoveries. Literature. Art. Archeology. Yearbook of 1974] (M. : Nauka, 1975), 71-74, here 71.

46. Biblioteka literatury drevnei Rusi [Library of the literature of Ancient Rus'] v. 13 : XVI vek, (XVI century] (SPb. : Nauka, 2005), 406-425, here 416, 420, 422.

47. Biblioteka literatury drevnei Rusi v. 10 : XVI vek, (SPb. : Nauka, 2000), 556.

48. Biblioteka literatury drevnei Rusi v. 13 : XvI vek, 304-53, here 322.

49. Elena Aleksandrovna Ryzhova, Antonievo-Siiskii monastyr': Zhitie Antoniia Siiskogo. Knizhnye tsentry russkogo severa [The Antonii of Siisk monastery. The life of Antonii of Siisk. Book centers of the Russian north] (Syktyvkar : Izdatel'stvo Syktyvkarskogo universiteta, 2000), on Vasilii III 268, 269 (but not 296) ; on Ivan IV 301, 323-325.

50. Biblioteka literatury drevnei Rusi v. 13 : XVI vek, 668-677, here 676.

51. Arkhimandrit Makarii, Iz istorii russkoi ierarkhii XVI veka, 186 (narrative), 196 n. 127 (letter from one cleric to another), 205 (letter from one cleric to another), 207, 208, 209 (narrative), 222, 227 (instruction by a bishop summarizing the "Council of One Hundred Chapters" to the clergy of an eparchy), 242 (book acquisition notice in monastery). Note that "autocrat" did not appear in an epistle by an archbishop to a city on the construction of a church authorized by Ivan (273-74) or a construction inscription on the "tsar's doors" of a church (273-74).

52. Lev Aleksandrovich Dmitriev, ed., Povest' o zhitii Mikhaila Klopskogo [Tale of the life of Mikhail of Klopsk] (M. - L. : Izdatel'stvo A.N. SSSR, 1958), 166-167 ; Stepennaia kniga tsarskogo rodosloviia, tom II, 316.

53. PSRL 3 (SPb. : Tipografiia Eduarda Pratsa, 1841), 254, left column (Novgorod III) ; PSRL 6 (SPb. : Tipografiia Eduarda Pratsa, 1853), 301 (Sofia II) ; PSRL 34 (M. : Nauka, 1978), 221 ("Moscow Little Chronicle," Moskovskii letopisets); Aleksandr Ivanovich Tsepkov, ed., Novgorodskie letopisi. Kniga vtoraia (Riazan': "Aleksandriia”, 2002), 329 (Continuation of the "Novgorodian Little Chronicle on Godly Churches" (Letopisets novgorodskii tserkvam bozhiim).

54. Pamiatniki literatury drevnei Rusi. Seredina XVI veka [Monuments of the Literature of Ancient Rus'. The Middle of the XVI century] (M. : Khudozhestvennaia literatura, 1985), 328-329, 358-359, 380-381, 426-427, 440-441, 442-443, 492-493, 510-511, 522-523, 524-525, 554-555, 556-557, 560-561 (with matching modern Russian translation). Earlier edition: G.N. Moiseeva, ed., Kazanskaia istoriia [Kazan History], (M. - L. : Izdatel'stvo A.N. SSSR, 1954), 112, 129, 172.

55. Platon G. Vasenko, "Kniga stepennaia tsarskogo rodosloviia" i ego znachenie v drevnerusskoi istoricheskoi pis'mennosti ["The Book of Degrees of Imperial Genealogy" and its significance in old Russian historical literature]. Chast' Pervaia (SPb. : Tipografiia I.N. Skorokhodova, 1904), 202-203; V. Mansikka, "Zhitie Aleksandra Nevskogo. Razbor redaktsii i tektsa [The Life of Alexander Nevskii, Survey of redactions and the text]" in Pamiatniki drevnei pis'mennosti i iskusstva [Monuments of ancient literature and art] no. 180 (1913), $2^{\text {nd }}$ section, 106, from Tipografskaia biblioteka, No. 346, 395, 1328 (1594). The text also contained a reference to the epithet "Groznyi" (at this date still "Awe-Inspiring," not "the Terrible") probably applied to Ivan III, not Ivan IV, which was not discussed in Charles J. Halperin, "The Metamorphosis of Ivan IV into Ivan the Terrible," in F.B. Uspenskii, ed., Miscellanea Slavica. Sbornik statei k 
70-letiiu Borisa Andreevicha Uspenskogo (M. : Indrik, 2008), 379-397 or Edward L. Keenan, "How Ivan Became 'Terrible'," in Harvey Goldblatt, Nancy Shields Kollmann, eds., Rus' Writ Large : Language, Histories, Cultures. Essays Presented in Honor of Michael S. Flier on His Sixty-Fifth Birthday $=$ Harvard Ukrainian Studies 28 (2006) : 521-42. My sincerest appreciation to Donald Ostrowski for consultation on the Mansikka text.

56. Kolobkov, Mitropolit Filipp i stanovlenie moskovskogo samoderzhaviia, Oprichnina Ivana Groznogo, 554-594, here 558.

57. O.A. Derzhavina and E.V. Kolosova, ed., Skazanie Avraamiia Palitsyna [The Narration of Avramii Palitsyn] (M. - L.: Izdatel'stvo A.N. SSSR, 1955), 101, 250 ; Andrei Lyzlov, Skifskaia istoriia [The Scythian History] (M. : Izdatel'stvo "Nauka", 1990), 61.

58. Vasilii Vasil'evich Kalugin, Zhitie Trifona Pechengskogo, prosvetitelia saamov v Rossii i Norvegii [The Life of Trifon of Pechenga, enlightener of the Saamy in Russia and Norway] (M. : Drevnekhranilishche, 2009), 184, 191, 205, 525-526.

59. Natal'ia Vasil'evna Ramazanova, Moskovskoe tsarstvo v tserkovno-pevcheskom iskusstve XVI -XVII vekov [The Muscovite kingdom in church-choral art of the XVI-XVII centuries] (SPb. : Dmitrii Bulanin, 2004), 125, 159.

60. V.I. Malyshev, ed., Povest' o prikhozhdenii Stefana Batoriia na grad Pskov [The Tale of the attack of Stefan Batory on the city of Pskov] (M. - L. : Izdatel'stvo A.N. SSSR, 1952), 75, 77.

61. R.P. Dmitrieva, ed., Povest' o Petre i Fevronii ([The Tale of Petr and Fevroniia] L. : Nauka, Leningradskoe otdelenie, 1979), 211, 217, 218, 219, 220.

62. Aleksandr Aleksandrovich Zimin, ed., Sochineniia I. Peresvetova [The Works of I. Peresvetov] (M. - L. : Izdatel'stvo A.N. SSSR, 1956), 162. See Val'denberg, Drevnerusskiia ucheniia o predelakh tsarskoi vlasti, 331-333.

63. Dvorkin, Ivan the Terrible as a Religious Type, 35.

64. Andrei Karavashkin, Literaturnyi obychai Drevnei Rusi [Literary customs of Ancient Rus'] (M. : ROSSPEN, 2011), 461-484, here 482-483.

65. Lev Aleksandrovich Dmitriev, Dmitrii Sergeevich Likhachev, eds., Pamiatniki literatury drevnei Rusi : Konets XV- pervaia polovina XVI veka [Monuments of the literature of Ancient Rus'. End of the of XV and first half of the XVI century] (M. : Khudozhestvennaia literatura, 1984), 512-515 (original text and facing modern Russian translation). Karpov's vocabulary has been elucidated in a variety of ways; for one theory, see Andrei L'vovich Iurganov, Kategorii russkoi srednevekovoi kul'tury [Categories of Russian medieval culture] (M. : MIROS, 1998), 65-67. On this monograph see Charles J. Halperin, "Cultural Categories, Councils and Consultations in Muscovy, A.I. Filiushkin, Istoriia odnoi mistifikatsii. Ivan Groznyi i "Izbrannaia Rada" [The History of a Mystification : Ivan the Terrible's "Chosen Council"], A.L. Iurganov, Kategorii russkoi srednevekovoi kul'tury, Sergei Bogatyrev, The Sovereign and his Counsellors: Ritualized Consultation in Muscovite Political Culture, 1350s - 1570s [review article of three books]," Kritika, 3, 4 (2002) : 653-664.

66. Szeftel, "The Title of the Muscovite Monarch," 66 may have been correct that no lay subjects ever addressed Ivan as "autocrat" because that word was not part of his title but it would be fair to say that Karpov was a lay author who implied that the ruler of Moscow was an "autocrat."

67. G.N. Moiseeva, Valaamskaia beseda - pamiatnik russkoi publitsistiki serediny XVI veka [The Discussion of Valaam - a monument of Russian publicistics of the middle of the XVI century] (M. L. : Izdatel'stvo A.N. SSSR, 1958), 163. See Val'denberg, Drevnerusskiia ucheniia o predelakh tsarskoi vlasti, 303-305. How this made the text an expression of anti-autocratic sentiment by boyars, per Vasilii Kliuchevskii, Boiarskaia Duma Drevnei Rusi [Boyar Council of Ancient Rus], $3^{\text {rd }}$ ed. (M. : Sinodal'naia Tipografiia, 1902), 249, escapes me.

68. Sergei Bogatyrev, The Sovereign and His Counsellors : Ritualised Consultations in Muscovite Political Culture, 1350s-1570s (Saarijärvi : Gummerus, 2000). On this monograph see Halperin, "Cultural Categories, Councils and Consultations in Muscovy," 673-683. 
69. John L.I. Fennell, ed., Prince A.M. Kurbsky's History of Ivan IV (Cambridge: Cambridge University Press 1965), 82-83. Objections to the authenticity of Kurbskii's "History" by Edward L. Keenan, Jr., "Putting Kurbskii in His Place, or : Observations and Suggestions Concerning the Place of the History of the Grand Prince of Moscow in the History of Muscovite Literary Culture," Forschungen zur osteuropäischen Geschichte [hereafter FOG] 24 (1978) : 131-161 and by Brian Boeck in "Eyewitness or False Witness ? Two Lives of Metropolitan Filipp of Moscow," JbfGOE, 55, 2 (2007) : 161-77 and "Miscellanea Attributed to Kurbskii. The Seventeenth Century in Russia Was More Creative Than We Like to Admit," Kritika, 13 (2012) : 955-963, a review article of Konstantin Iur'evich Erusalimskii, Sborniki Kurbskogo. [Kurbskii Miscellanies] Tom I Issledovanie knizhnoi kul'tury [Investigation of bookish culture] (M. : Znak, 2009), are unconvincing. On Keenan see Charles J. Halperin, "Edward Keenan and the Kurbskii-Groznyi Correspondence in Hindsight," JbfGOE, 46 (1998) : 376-403, here 396-398. Boeck argued that the "History" is secondary to the vita of Metropolitan Filipp written in the 1590s despite the fact that there is no direct textual borrowing between the two texts. The similarly in content between the two expositions of Filipp's conflict with Ivan is much more easily explained by the fact both authors as they claimed were relying upon common but not identical oral sources which presented events in chronological sequence than by the elaborate, artificial, convoluted and consciously duplicitous creative-writing techniques Boeck attributed to the author of the "History" to mask his borrowing, a process which would have been unique in seventeenth-century Muscovite literature and completely unlike the commonplace transfer of passages from one person to another or the misquotation and mis-attribution of texts quoted from memory ubiquitous in Rus' literature. Other elements of Boeck's theory of the origin of Kurbskii's "History" can also be questioned but comprehensive criticism awaits Boeck's completion of a monograph on the question. For now it is imperative only to call attention to Boeck's comment on Erusalimskii's failure to analyze textual relations between the "History" and Guagnini: "Once again, further study of the [Kurbskii] miscellanies [which contain the "History"] is sacrificed to save the [traditional] dating and attribution" (Boeck, "Miscellanea Attributed to Kurbskii," 962, my emphasis-CJH). This unfortunate phrasing implied that Erusalimskii deliberately avoided researching certain issues relevant to the authenticity of Kurbskii's "History" because Erusalimskii knew that such study would impugn his conclusion. Professor Boeck assured me (discussion, 23 November 2013, Boston) that he did not realize that his words could be interpreted to make such a slanderous accusation against Erusalimskii and that he did not intend to do so.

70. John L.I. Fennell, tr., The Correspondence of Prince A.M. Kurbsky and Tsar Ivan IV of Russia 1564-1579 (Cambridge: Cambridge University Press, 1963), 236-237 (facing Slavonic text and modern English translation). My thanks to Brian Boeck for calling my attention to this passage.

71. I see no convincing reason to doubt the authenticity of this work. Halperin, "Edward Keenan and the Kurbskii-Groznyi Correspondence in Hindsight."

72. The Correspondence of Prince A.M. Kurbsky and Tsar Ivan IV of Russia 1564-1579, 26-27, 46-47 (facing Slavonic text and modern English translation). I have simplified Fennell's editing.

73. Dmitrii Sergeevich Likhachev, Iakov Solomonovich Lur'e, ed., Poslaniia Ivana Groznogo [Epistles of Ivan the Terrible] (M. - L. : Izdatel'stvo A.N. SSSR, 1951), 243, 259.

74. Despite which Karavashkin, Russkaia srednevekovaia publististika, 312, 314, 351 referred to Kurbskii's attitude toward Ivan's concept of "autocracy" (samoderzhavstvo), discussed 131, 204, 317, 321, 403-6.

75. Most scholars date the so-called "vita of Grand Prince Dmitrii Donskoi" (Slovo o zhitii i o prestavlenii velikogo kniazia Dmitriia Ivanovicha, tsaria russkogo [Oration on the life and death of Grand Prince Dmitrii Ivanovich, Russian Tsar']) to the middle of the fifteenth century. Although this text lauded Donskoi as "tsar" it did not employ the word "autocrat" for Donskoi or any other ruler mentioned, including St. Vladimir. See Gianfranco Giraudo, "Car', Carstvo et termes corrélatifs dans les textes russe de la deuxième moitié du $\mathrm{XVI}^{\mathrm{e}}$ siècle," in Popoli e spazio 
romano tra diritto e profezia (Da Roma alla terza Roma. Documenti e Studi. Studii III, 21 April 1983 : Naples: Edizioni Scientifiche Italiane, 1986), 545-572, here 560, on the autonomy of the concept of "autocrat" from that of "tsar."

76. Iurganov, Kategorii russkoi srednevekovoi kul'tury, 216-305, argued that as ruler Ivan alone possessed "autonomy" (vol'nost') ; he did not affiliate that attribute to a concept of "autocracy," which was not discussed in this monograph.

77. Neubauer, Car und Selbstherrscher, 40 ; Jaako Lehtovirta, Ivan IV as Emperor. The Imperial Theme in the Establishment of Muscovite Tsardom, dissertation, University of Turku, 1999, 249 ; John Eric Myles, "The Muscovite Ruling Oligarchy of 1547-1564: its Composition, Political Behavior, and Attitudes towards Reform," dissertation, Oxford University (Bodleian), 1987, 83, 170 ; Hartmut Rüß, Herren und Diener. Die soziale und politische Mentalität des Russischen Adels. 9.-17. Jahrhundert (Cologne : Böhlau Verlag 1994), 465.

78. I owe this suggestion to one of the anonymous referees of this article.

\section{ABSTRACTS}

Although historians generally refer to Ivan as an "autocrat" (samoderzhets) and his regime as an "autocracy" (samoderzhavstvo), Ivan was not crowned with the title "autocrat" in 1547 and did not use the word very often in his writings. Ivan was familiar with at least three meanings of the word "autocrat," an independent ruler, a pious ruler, and an unlimited ruler, but he relied upon his title of "tsar" as the basis for his legitimacy. Although by "autocrat" and "autocracy" historians almost always mean an unlimited ruler, the most common usage of the term “autocrat" in Ivan IV's Muscovy was a pious ruler.

Bien que généralement les historiens qualifient Ivan IV d'«autocrate» et son régime d'«autocratie » (samoderžavstvo), en 1547, Ivan n'a pas été couronné «autocrate » et n'a pratiquement pas eu recours à ce mot dans ses écrits. Ivan IV connaissait au moins trois des acceptions possibles de l'« autocrate ", souverain indépendant, pieux, et détenteur d'un pouvoir illimité, mais il appuyait sa légitimité sur son titre de «tsar». La plupart du temps, par "autocrate», les historiens entendent souverain absolu, cependant, dans la Moscovie d'Ivan, l'acception la plus commune de ce terme était celle de dirigeant pieux.

\section{AUTHOR}

\section{CHARLES J. HALPERIN}

Bloomington, IN, chalperi@indiana.edu 